\title{
Travel-based Multitasking on Public Transport: An Empirical Research in Hungary
}

\author{
András Munkácsy ${ }^{1 *}$, Imre Keserü², Miklós Siska ${ }^{1}$ \\ ${ }^{1}$ Department for Transport Management, Research Centre for Transport Development, KTI Institute for Transport Sciences \\ NLtd., Than Károly utca 3-5, H-1119 Budapest, Hungary \\ ${ }^{2}$ Department of Business Technology and Operations (BUTO), Mobility, Logistics \& Automotive Technology Research Centre \\ (MOBI), Vrije Universiteit Brussel, Pleinlaan 2, 1050 Brussels, Belgium \\ *Corresponding author, e-mail: munkacsy.andras@kti.hu
}

Received: 04 March 2020, Accepted: 10 March 2020, Published online: 13 October 2021

\begin{abstract}
On the basis of a survey addressing travel behaviour in 4707 households in Hungary in 2016, activities of passengers (especially on non-local public transport services) are analysed in this paper. Descriptive statistics is applied to provide a general view of household survey results about activities while travelling. K-means clustering is used for the analysis of travel-based multitasking on public transport and chartered commuter bus services. On the basis of one of the very first travel-based multitasking studies in Hungary, we concluded that the prevailing activity is talking to others, followed by relaxing or daydreaming, and listening to music/radio. Based on the outcomes of the clustering of public transport journeys by age of passengers, the main finding is that the use of electronic devices decreases with age and the characteristics of clusters in terms of other activities are diverse.
\end{abstract}

Keywords

travel-based multitasking, travel behaviour, public transport, household survey, Hungary

\section{Introduction}

Travel time has been in the focus of transport research for a long time. One of the starting points was the work of Szalai (1972) analysing daily time use in urban areas in 12 countries, concluding that travel accounts for approximately 1 hour per day irrespective of country. A few decades later, Schäfer and Victor (2000) concluded that a person dedicates on average 1.1 hour per day to travel. Fleischer and Tir (2016) summarised research on the travel time budget from the last half-century in Hungary and found that the time spent travelling per day had not changed considerably for the past decades (Table 1).

This average one-hour travel time has, however, been traditionally considered as a waste of time since it was deemed that people cannot engage in productive activities

Table 1 Transport time budget in Hungary

\begin{tabular}{lcc}
\hline Year & Age & Average time spent in transport per day (min) \\
\hline $1976 / 1977$ & $15-69$ & 63.0 \\
\hline $1986 / 1987$ & & 61.8 \\
$1999 / 2000$ & $15-74$ & 59.4 \\
$2009 / 2010$ & & 65.2 \\
\hline
\end{tabular}

Source: data from Fleischer and Tir (2016) while travelling. This assumption has driven the definition of the value of travel time, which is key factor in cost benefit analysis (see e.g. González, 1997; Metz, 2008; Wardman, 1998). Nevertheless, recently, due to the increase in the use of portable information and communication technology (smartphones, tablets, laptops) the notion of useless travel time has been criticised by many studies. There is growing evidence that people engage in productive and enjoyable activities while travelling i.e. they carry out travel-based multitasking (Keserü and Macharis, 2018).

In the context of multitasking, two combinations of activities may be differentiated:

- switchtasking (or task-switching), i.e. carrying out and switching attention between multiple attention-requiring tasks at the same time;

- background tasking, i.e. performing a task and doing other (passive) activity in parallel that is not competing for attention.

Although multitasking is usually attached to the first meaning, travel-based multitasking covers the latter in 
most cases. Travel may be the primary activity in case of travel modes requiring relevant cognitive effort (e.g. walking, cycling, or driving a car), while secondary activities are passive (e.g. listening to music, talking to others). In the case of passengers, the task being performed on board by a person may be considered the primary activity and travelling as the background one.

Our knowledge of what activities passengers perform and would like to perform is important from various perspectives. Public transport operators can adapt their services to passenger needs to support travel-based multitasking (e.g. by providing free Wi-Fi and power outlets). Vehicle manufacturers may be able to adapt vehicle design to the needs of work or leisure activities on board (e.g. seat spacing, tables, lights) (Van der Waerden et al., 2009). The benefits of being able to spend travel time productively can also contribute to a modal shift to public transport (Wardman and Lyons, 2016).

In this article, a brief analysis of travel-based multitasking is described on the basis of a household survey addressing travel behaviour in Hungary. Only journeys by passengers (especially on buses and trains) are considered. It is expected that by one of the very first evidences from Central and Eastern Europe and in line with the growing literature of this topic (e.g. Kouwenhoven and de Jong, 2018; Varghese and Jana, 2018) outcomes may pave the way for better understanding of travel time use in different cultural and spatial contexts (in this case, Hungary).

\section{Data and methods}

\subsection{Survey}

Previous research applied both qualitative (e.g. ethnography, focus groups, semi-structured interviews) and quantitative methods (e.g. interviews or observations) to detect multitasking characteristics (Keserủ and Macharis, 2018). The present study is based on a household survey carried out as part of a project aiming to define Origin-Destination (OD) matrices in Hungary in 2016/2017 (Siska and Szűcs, 2017). The survey was intended to understand general travel behaviour by asking for a detailed account of all journeys made on the last full working day and weekend/ holiday preceding the survey. One question addressed activities during travel. Only non-local journeys (and local legs of non-local journeys) are considered here, as the main project addressed travel behaviour between settlements, and household surveys were carried out mainly in towns and rural areas (and only rarely in large cities).
Concerning travel-based multitasking related to a journey, respondents could choose one item from the following: reading; work-related activities; studying; talking to others; listening to music or radio; talking on the phone; messaging; browsing the internet, playing, watching movies (on mobile devices); eating or drinking; relaxing; doing nothing; other. Based on experience during the data collection and data processing, the overlapping categories of "doing nothing" and "relaxing" have been merged. The "other" option has been indicated merely by drivers (e.g. professional bus drivers), thus their answers have been ignored.

\subsection{Sample}

In total, 4707 households were surveyed in 14 districts and 2 cities of Hungary in the autumn of 2016. The number of respondents was 9281, who provided information about 20,332 journeys. As mentioned above, not all journeys are considered in the present study: ignoring local journeys and those done by non-motorized individual modes or as a driver of a motor vehicle, the total number of analysed journeys is reduced to 4385.3374 were taken on a weekday and 1011 on weekends or holidays.

The full sample (Table 2, KSH, 2013) includes journeys by all transport modes (in total, 4385). The reduced sample consists of journeys by public transport (train, bus) and chartered commuter bus services (1973 journeys).

Representativeness in terms of sex, age groups and household size seems to be good with respect to the population of Hungary. Some differences are due to random sampling and some others may be explained by the following reasons:

- data was collected for a large scale project (to define Origin-Destination matrices for all modes in Hungary) and the household survey aimed to understand travel behaviour of motorists, i.e. mostly adults, thus children are underrepresented (and consequently other age categories are overrepresented) in the full sample;

- lower proportion of inactive respondents may be due to the changes of unemployment rates from 2011 (11.1\%) to 2016 (5.1\%) in Hungary.

In the sample, most journeys on workdays are to work or school (54.4\%), visiting friends and relatives or leisure (in sum, $23.6 \%$ ) and shopping (12.0\%). A majority (74.9\%) takes this journey on a regular basis, i.e. usually on all workdays but at least once a week. Only one out of ten (10.7\%) journeys are taken rarely or for the first time ever. 
Table 2 Sample characteristics

\begin{tabular}{|c|c|c|c|c|c|}
\hline \multicolumn{2}{|c|}{ Characteristics } & \multirow{2}{*}{$\begin{array}{c}\begin{array}{c}2016 \\
\text { (full sample) }\end{array} \\
52.8\end{array}$} & \multirow{2}{*}{\begin{tabular}{c}
\multicolumn{2}{c}{2016} \\
(reduced sample) \\
$\%$ \\
\\
\end{tabular}} & \multicolumn{2}{|c|}{$\begin{array}{c}2011 \\
\text { (census in Hungary) }\end{array}$} \\
\hline \multirow{2}{*}{ Sex } & Female & & & 52.2 & \\
\hline & Male & 47.2 & 45.0 & 47.8 & \\
\hline \multirow{5}{*}{ Age } & $6-18$ & 6.9 & 15.1 & 17.3 & $5-19$ \\
\hline & $19-30$ & 14.8 & 22.7 & 12.6 & $20-29$ \\
\hline & $31-45$ & 25.7 & 24.0 & 23.8 & $30-44$ \\
\hline & $46-60$ & 25.6 & 26.5 & 22.1 & $45-59$ \\
\hline & $60+$ & 27.1 & 11.7 & 24.2 & $60-$ \\
\hline \multirow{5}{*}{ Education } & Grade 0 to 7 & 14.8 & 3.1 & 12.4 & \\
\hline & Grade 8 & 23.1 & 23.2 & 19.3 & \\
\hline & Vocational training & 27.3 & 34.8 & 25.2 & \\
\hline & High school & 25.8 & 28.9 & 25.0 & \\
\hline & Higher education & 9.0 & 9.6 & 18.1 & \\
\hline \multirow{3}{*}{ Occupation } & Student (dependent) & 34.0 & 21.1 & 35.4 & \\
\hline & Manager, employed, self-employed & 46.1 & 66.4 & 39.7 & \\
\hline & Inactive (pensioner, child care, unemployed, other) & 19.9 & 12.5 & 24.9 & \\
\hline
\end{tabular}

Source: own collection; census data from KSH (2013)

\subsection{Methods}

In this article, descriptive statistics is applied to provide a general view of household survey results about activities while travelling, then advanced statistics, namely cluster analysis, is used for the analysis of travel-based multitasking on public transport and chartered commuter bus services. This aims to define relatively homogeneous groups of journeys and, subsequently, passengers and their activities, in order to understand their characteristics. This may allow the study of multitasking by features like age or employment status. The analysis is done by non-hierarchic K-means clustering. The number of clusters have been defined arbitrarily, by preliminary assumptions, as described below.

\section{Results and discussion}

\subsection{Travel-based multitasking of passengers in general}

If journeys by passengers of all transport modes are considered ( $n=4385$, full sample), talking to others is the most frequent activity while travelling (approx. $40 \%$ ), followed by relaxing (30\%) and listening to music or radio (15\%). Other activities requiring the use of mobile devices (talking on the phone, messaging, browsing, playing, etc.) account for 5-6\%. However, no relevant differences are to be noted between men and women. Women tend to talk to others, read or study, while men use mobile devices or relax in a higher proportion. Some further outcomes are as follows:
- work-related activities are done primarily by those travelling for work-related purposes;

- similarly, studying is the most frequent among people going to school (and those not revealing their trip purposes are studying in a similar proportion);

- people going to school use electronic devices in the highest proportion;

- reading is carried out primarily by people going to work.

Some possible correlation of travel mode and multitasking may be observed even without further analysis. A majority of passengers (three out of four people) talk; the rest relax or listen to music/radio (10\% each) in passenger cars. The range of activities seems to be the most diverse among train passengers: although most of them relax, respondents maybe due to a presumably longer journey - report a higher rate of reading (15.8\%), studying ( $8.1 \%$ ) and use of electronic devices than people using other modes. Talking to others and relaxing are also relevant activities but not to the extent of, e.g. bus passengers. Reading (3.3\% of bus passengers) and studying $(1.5 \%)$ are rare in road passenger transport. People on buses talk, listen to music/radio or, in the largest proportion, do nothing (relaxing, daydreaming, etc.).

The comparison of these outcomes to data from other countries is difficult due to the lack of standard multitasking categories, the diverse composition of the samples (i.e. which transport modes are included) and the lack of 
cross-sectional data from the same time periods (as technological development and changes in smartphone penetration can change multitasking patterns quickly) (Keserü and Macharis, 2018). Therefore, any comparison to other countries is only indicative. Nevertheless, previous research has shown that, similarly to the results of this research, the most prevalent multitasking activities are talking to other passengers (Mokhtarian et al., 2015; Patriarche and Huynen, 2014; Timmermans and Van der Waerden, 2008; Zhang and Timmermans, 2010) and relaxing, including window gazing, sleeping, and doing nothing (Guo et al., 2015; Russell et al., 2011; Vilhelmson et al., 2011; Zhang and Timmermans, 2010). At the same time, a significant increase has been detected in the use of ICT devices over time in the UK (Lyons et al., 2016) and the US (Schwieterman and Battaglia, 2014), where longitudinal data is available.

\subsection{Travel-based multitasking on public transport}

In sum, 1973 journeys by 1084 passengers have been analysed to review the activities while travelling on public transport (train, bus) and chartered commuter bus services. In this reduced sample, the proportion of women is $55.5 \%$, the average age is 39.1 years. With respect to the full sample, working people are overrepresented and their distribution is different to the full sample: the number of managers and self-employed is low $(<1 \%)$ and, consequently, the proportion of other workers is higher than in the full sample. It seems that managers - most probably due to their income, higher car ownership rate, lifestyle, schedule and other personal motivation - do not use public transport or company buses on these kinds of trips. In sum, students make $21.1 \%$, active workers $66.4 \%$, and inactive people $12.5 \%$ of the journeys.

Most journeys in the sample are done by public bus services $(67 \%)$, followed by chartered commuter buses (18\%) and trains $(15 \%)$. Obviously, commuting prevails (to work $30 \%$, to school $11.1 \%$ ), and the share of other trip purposes is much less considerable (shopping $3.7 \%$, health-related $3.4 \%$, visiting friends and relatives $2.8 \%$, running errands $2.1 \%$, leisure $1.9 \%$, work-related travel $1.3 \%$ ). Furthermore, the purpose of returning home (43.8 \%) is also considered. As mentioned above, journeys have been grouped by a preliminary assumption, namely that age (and related socioeconomic status) determines clusters. Four clusters have been created: early, young, middle and late adulthood. Clusters are seen in Table 3. It may be underlined that journeys (and not people) are clustered here.
In sum, age-based clustering assumptions seem to be correct. Furthermore, not only personal (age-related), but also travel-based multitasking characteristics are different in these groups. In addition to what is said in the table, it may be highlighted that:

- relaxing or doing nothing (daydreaming or other passive activities), the most frequent among all activities while travelling on public transport services increasingly prevails with age;

- in contrast, the proportion of talking to others and using electronic devices decreases with age;

- the only activity requiring the use of electronic devices that is present in all four clusters is listening to music/radio, however, it is rare in the late adulthood group (1.2\%);

- share of work-related activities is minimal, it is the highest in Cluster 3 (0.6 \%);

- studying is almost negligible in Clusters 2 to 4 $(<0.2 \%)$;

- the proportion of reading is similar in all clusters (10\% in Cluster 3 , and 8 to $9 \%$ in the others);

- eating or drinking is rare in all clusters, and these activities completely disappear in higher age groups.

\section{Conclusion}

The study revealed what kind of activities are performed during non-local journeys, especially on public transport vehicles (train and bus) and chartered commuter bus services (in 2016). In conclusion, it may be highlighted that on the basis of one of the very first travel-based multitasking research in Hungary - the prevailing activity on non-local journeys is talking to others, followed by relaxing or daydreaming, and listening to music/radio. The low proportion of activities carried out on smartphones or tablets may be explained by the growing but still relatively low rate of smartphone ownership and mobile internet access in 2016. By the outcomes of clustering of public transport journeys by the age of passengers, the main finding, on the one hand, is that the use of electronic devices decreases with age. On the other hand, characteristics of clusters are quite diverse in terms of other activities.

One of the main limitations of the present study is the applied data collection method. People had to report on their activities while travelling one or several days after the journey, so it may be assumed that some of them chose the activity they usually do on this type of journeys (e.g. nothing) instead of what they actually did (e.g. eventually 
Table 3 Sample characteristics

\begin{tabular}{|c|c|c|c|c|}
\hline \multirow{2}{*}{ Variables } & \multicolumn{4}{|c|}{ Clusters } \\
\hline & 1 & 2 & 3 & 4 \\
\hline $\begin{array}{l}\text { Group size (no. of } \\
\text { journeys) }\end{array}$ & 752 & 585 & 468 & 168 \\
\hline Age (years) & 20.7 & 39.9 & 54.8 & 71.4 \\
\hline Deviation & 5.4 & 5.0 & 4.3 & 5.1 \\
\hline Occupation & $\begin{array}{c}\text { mostly students }(55 \%) \text { and } \\
\text { employees }(40 \%)\end{array}$ & $\begin{array}{c}\text { mainly intellectual } \\
\text { employees }(30 \%) \text { and } \\
\text { manual workers }(64 \%)\end{array}$ & $\begin{array}{c}\text { mainly intellectual }(22 \%) \\
\text { and physical workers }(65 \%) \text {, } \\
\text { some pensioners }(8 \%)\end{array}$ & $\begin{array}{l}\text { pensioners in majority } \\
\qquad(90 \%)\end{array}$ \\
\hline Education level & $\begin{array}{l}\text { ongoing studies are } \\
\text { dominant }\end{array}$ & $\begin{array}{l}\text { the cluster with the highest } \\
\text { levels: high school } 32 \% \text {, } \\
\text { higher education } 13 \% \text {; but } \\
\text { mainly vocational training } \\
(44 \%)\end{array}$ & $\begin{array}{l}\text { mainly vocational training } \\
(47 \%) \text { and less higher } \\
\text { education degrees than in } \\
\text { younger groups }\end{array}$ & $\begin{array}{c}\text { mostly primary education } \\
(42 \%) \text { and vocational } \\
\text { training }(33 \%)\end{array}$ \\
\hline Household size (pers.) & 3.9 & 3.5 & 2.8 & 1.9 \\
\hline Deviation & 1.5 & 1.3 & 1.3 & 1.0 \\
\hline $\begin{array}{l}\text { Financial status of the } \\
\text { household }\end{array}$ & \multicolumn{4}{|c|}{ rating of the household's financial status decreases with age } \\
\hline
\end{tabular}

the proportion of the use of train is similar in all groups (14 to $16 \%$ )

Travel mode

the use of chartered commuter bus services is one out of four travels by chartered commuter bus services

no use of chartered commuter buses at all rare $(12 \%)$

\begin{tabular}{|c|c|c|c|c|}
\hline Trip purpose & mainly to school & mainly to work & $\begin{array}{l}\text { mainly to work but also } \\
\text { some health-related trip }\end{array}$ & $\begin{array}{l}\text { mainly health related trips } \\
\text { and shopping, visiting } \\
\text { friends or relatives }\end{array}$ \\
\hline $\begin{array}{l}\text { Frequency of this } \\
\text { journey }\end{array}$ & $\begin{array}{c}\text { mainly on all weekdays } \\
(74 \%) \text {, or several times per } \\
\text { week }(15 \%)\end{array}$ & $\begin{array}{l}\text { similar proportions like in } \\
\text { cluster 1: weekdays } 71 \% \text {, } \\
\text { several times per week } 14 \%\end{array}$ & $\begin{array}{l}\text { the share of "several times } \\
\text { per week" is higher than } \\
\text { in Clusters } 1 \text { and } 2(21 \%) \text {; } \\
\text { weekdays } 59 \%\end{array}$ & $\begin{array}{l}\text { several times per month } \\
32 \% \text {, less often } 27 \% \text {, daily } \\
\text { frequency on weekdays is } \\
\text { rare }(4 \%)\end{array}$ \\
\hline Travel-based & $\begin{array}{l}\text { studying only appears here } \\
(7 \%)\end{array}$ & & $\begin{array}{l}\text { the highest proportion of } \\
\text { reading among clusters } \\
\qquad(10 \%)\end{array}$ & $\begin{array}{l}\text { no talking on the phone, no } \\
\text { messaging, no browsing }\end{array}$ \\
\hline
\end{tabular}

multitasking (activities

while travelling)

the proportion of relaxing increases with age (30\% in Cluster 1; $63 \%$ in Cluster 4$)$

the proportion of talking to others (33\% in Cluster 1; $27 \%$ in Cluster 4$)$ and the use of electronic devices $(23 \%$; $1 \%)$ decreases with age

talking on the phone). However, the data collected by the household survey allows a deeper analysis of the personal and journey-related circumstances, which would not have been possible by a different data collection method (e.g. by observations).

In the next project phases, further statistical analysis can lead to findings that may be used for the assessment of travel time valuation and, subsequently, for reconsidering mobility planning procedures (guidelines, manuals, etc.). Future research directions may be the comparison with observations in other contexts and the update of the present research by new observations in Hungary.

\section{Acknowledgement}

The data collection was supported by a project co-financed by the Connecting Europe Facility (CEF) and the State of Hungary. This paper was originally submitted to and accepted for presentation at Transport Research Arena (TRA2020), scheduled for April 2020, cancelled due to the COVID-19 pandemic. 


\section{References}

Fleischer, T., Tir, M. (2016) "The transport in our time budget", Regional Statistics, 6(2), pp. 54-94. https://oi.org/10.15196/RS06204

González, R. M. (1997) "The value of time: a theoretical review", Transport Reviews, 17(3), pp. 245-266. https://doi.org/10.1080/01441649708716984

Guo, Z., Derian, A., Zhao, J. (2015) "Smart Devices and Travel Time Use by Bus Passengers in Vancouver, Canada", International Journal of Sustainable Transportation, 9(5), pp. 335-347. https://doi.org/10.1080/15568318.2013.784933

Keserü I., Macharis, C. (2018) "Travel-based multitasking: review of the empirical evidence", Transport Reviews, 38(2), pp. 162-183. https://doi.org/10.1080/01441647.2017.1317048

Kouwenhoven, M., de Jong, G. (2018) "Value of travel time as a function of comfort", Journal of Choice Modelling, 28, pp. 97-107. https://doi.org/10.1016/j.jocm.2018.04.002

KSH (2013) "2011. évi népszámlálás. 4. Demográfiai adatok" (Population census 2011. 4. Data on demography), Központi Statisztikai Hivatal (Hungarian Central Statistical Office), Budapest, Hungary. [online] Available at: https:/www.ksh.hu/docs/hun/xftp/idoszaki/ nepsz2011/nepsz_04_2011.pdf [Accessed: 15 September 2019] (in Hungarian)

Lyons, G., Jain, J., Weir, I. (2016) "Changing times - A decade of empirical insight into the experience of rail passengers in Great Britain", Journal of Transport Geography, 57, pp. 94-104. https://doi.org/10.1016/j.jtrangeo.2016.10.003

Metz, D. (2008) "The Myth of Travel Time Saving", Transport Reviews, 28(3), pp. 321-336. https://doi.org/10.1080/01441640701642348

Mokhtarian, P. L., Papon, F., Goulard, M., Diana, M. (2015) "What makes travel pleasant and/or tiring? An investigation based on the French National Travel Survey", Transportation, 42(6), pp. 1103-1128. https://doi.org/10.1007/s11116-014-9557-y

Patriarche, G., Huynen, P. (2014) "Gebruik van de Verplaatsingstijd door de Brusselaars: Analyse van de Mobiele Activiteiten op Weg naar de Werk- of Schoollocatie" (Use of travel time by residents of Brussels: analysis of mobile activities on the way to work or school), In: Macharis, C., Dobruszkes, F., Hubert, M. (eds.) Mobiliteit en logistiek in Brussel, VUBpress, Brussels, Belgium, pp. 83-114. (in Dutch)

Russell, M., Price, R., Signal, L., Stanley, J., Gerring, Z., Cumming, J. (2011) "What Do Passengers Do During Travel Time? Structured Observations on Buses and Trains", Journal of Public Transportation, 14(3), pp. 123-146. http://doi.org/10.5038/2375-0901.14.3.7

Schäfer, A., Victor, D. G. (2000) "The future mobility of the world population", Transportation Research Part A: Policy and Practice, 34(3), pp. 171-205.

https://doi.org/10.1016/S0965-8564(98)00071-8
Schwieterman, J., Battaglia, A. (2014) "The Digitally Connected Traveler: Measuring the Growing Use of Electronic Devices on Intercity Buses, Planes, and Trains 2010-2013", presented at the Transportation Research Board 93 ${ }^{\text {rd }}$ Annual Meeting, Washington DC, USA, Jan., 12-16, 2014, [online] Available at: https://trid.trb. org/view.aspx?id=1289560 [Accessed: 15 September 2019]

Siska, M., Szűcs, H. (2017) "A közlekedési szokásjellemzők alakulása, hatásuk a személygépkocsi-forgalomra" (Evolution of travel habits and their impact on passenger car traffic), Közlekedéstudományi Szemle (Scientific Review of Transport), 67(5), pp. 33-43. (in Hungarian) https://doi.org/10.24228/KTSZ.2017.5.4

Szalai, A. (ed.) (1972) "The use of time. Daily Activities of Suburban Population in Twelve Countries", Mouton \& Co., Paris, France.

Timmermans, H., Van der Waerden, P. (2008) "Synchronicity of Activity Engagement and Travel in Time and Space: Descriptors and Correlates of Field Observations", Transportation Research Record, 2054(1), pp. 1-9. https://oi.org/10.3141/2054-01

Van der Waerden, P., Timmermans, H., Van Neerven, R. (2009) "Extent, Nature, and Covariates of Multitasking of Rail Passengers in an Urban Corridor: A Dutch Case Study", Transportation Research Record, 2110(1), pp. 106-111. https://doi.org/10.3141/2110-13

Varghese, V., Jana, A. (2018) "Impact of ICT on multitasking during travel and the value of travel time savings: Empirical evidences from Mumbai, India", Travel Behaviour and Society, 12, pp. 11-22. https://doi.org/10.1016/j.tbs.2018.03.003

Vilhelmson, B., Thulin, E., Fahlén, D. (2011) "ICTs and Activities on the Move? People's Use of Time While Traveling by Public Transportation", In: Brunn, S. (ed.) Engineering Earth, Springer, Dordrecht, Netherland, pp. 145-154. https://doi.org/10.1007/978-90-481-9920-4_10

Wardman, M. (1998) "The Value of Travel Time: A Review of British Evidence", Journal of Transport Economics and Policy, 32(3), pp. 285-316. [online] Available at: https://www.jstor.org/ stable/20053775 [Accessed: 15 September 2019]

Wardman, M., Lyons, G. (2016) "The digital revolution and worthwhile use of travel time: implications for appraisal and forecasting", Transportation, 43(3), pp. 507-530. https://doi.org/10.1007/s11116-015-9587-0

Zhang, J., Timmermans, H. (2010) "Scobit-Based Panel Analysis of Multitasking Behavior of Public Transport Users", Transportation Research Record, 2157(1), pp. 46-53. https://doi.org/10.3141/2157-06 